\title{
UTILIZATION OF BEE (Apis mellifera) HONEY FOR VINEGAR PRODUCTION
}

\author{
EUNICE CASSANEGO ILHA * \\ ERNANI SEBASTIÃO SANT'ANNA ** \\ REGINA COELI OLIVEIRA TÔRRES * \\ ANNA CLAUDIA SIMAS PORTO * \\ ELZA MARIA MEINERT *
}

\begin{abstract}
Utilizou-se mel de abelhas (Apis melifera) para a obtenção de vinagre, com a perspectiva de diversificação dos produtos derivados do mel. 0 mosto foi preparado com mel diluído em água destilada, resultando numa solução com $21^{\circ}$ Brix, enriquecida com sulfato de amônio e fosfato de amônio e inoculada com fermento comercial desidratado (Saccharomyces cerevisiae) numa proporção de $4 \mathrm{~g} / \mathrm{L}$. A fermentação alcoólica ocorreu em temperatura ambiente, durante 24 horas. Um kilograma de mel rendeu cinco litros de hidromel com teor alcoólico em torno de $8 \%(\mathrm{v} / \mathrm{v})$, a partir de mosto com 17,11\% (p/v) de açúcares totais. A eficiência da fermentação alcoólica foi de $81,34 \%$. A fermentação acética foi realizada pelo método rápido, em fermentador vertical com capacidade de 15 litros. O vinagre obtido apresentou acidez em torno de $9 \%$ e teor alcoólico residual em torno de $1 \%(\mathrm{v} / \mathrm{v})$. O rendimento da fermentação acética ficou entre 91,24 e 97,21\%. A avaliação sensorial revelou índices de aceitação acima de $70 \%$, ou seja, 95,37\% para a aparência; $94,81 \%$ para cor; $79,07 \%$ para odor e $75,56 \%$ para sabor.
\end{abstract}

\section{INTRODUCTION}

Honey is produced practically in the whole world. From the worldwide production, $90 \%$ is consumed as table honey and $10 \%$ is distributed among the breadmaking process, the tobacco curing process, and the cosmetic and pharmaceutical industry. In addition, some sorts of products have been developed and can be manufactured at the home farm, with remarkable success. Some of these products are honey wine (mead), butter with honey, honey beer, yogurt with honey and liqueur (7).

* M.Sc. em Ciência dos Alimentos, Departamento de Ciência e Tecnologia de Alimentos, Universidade Federal de Santa Catarina (UFSC), Florianópolis, SC.

** Professor Titular, Departamento de Ciência e Tecnologia de Alimentos, UFSC, Florianópolis, SC (e-mail: ernani@cca.ufsc.br). 
China is very rich in honey resources, being the world largest producer of bee honey (15). However, lower quality eucalyptus and country mint honey represent $20 \%$ of the total annual production in this country. This type of honey has its utilization limited to food or pharmaceutical uses, because of its unpleasant smell and dark color. The utilization of this qualitatively lower type of honey is an important matter which has drawn the attention of specialists in that country (5).

VIDAL (16) makes references to bee honey utilization in the production of beverages such as wine in Europe, United States and Asia.

In 1993, Brazil produced 18,367,172 Kg of bee honey, being the second producer among the MERCOSUL countries. The State of Santa Catarina was the largest producer in the country in that year (15).

The aim of this study was to produce vinegar by utilizing bee honey as substrate, and to offer honey producers another alternative to diversify their production and supply the market with new products.

\section{MATERIAL AND METHODS}

\subsection{RAW MATERIAL}

The bee (Apis mellifera) honey utilized was bought at the local market (Florianópolis, SC, Brazil) in $25 \mathrm{Kg}$ packages. This material was maintained at room temperature.

\subsection{MICROORGANISMS}

Saccharomyces cerevisiae was used in alcoholic fermentation, after successive adaptations in the honey wort. The acetic fermentation was conducted by acetic acid bacteria from a non-pasteurized alcohol vinegar (strong vinegar), provided by a vinegar industry located in the city of Florianópolis.

\subsection{ALCOHOLIC FERMENTATION}

\subsubsection{Wort preparation}

Honey was diluted with distilled water to $21 \%$ total solids, which was determined by the utilization of a refratometer (JENA 265085).

Aiming to activate the fermentation, ammonium sulfate $(0.2 \mathrm{~g} / \mathrm{L})$ and ammonium phosphate $(0.02 \mathrm{~g} / \mathrm{L})$ were added to the diluted honey. 
Yeast (Saccharomyces cerevisiae) was added to this diluted and enriched honey after being dissolved in a proportion of $4 \mathrm{~g}$ of yeast $/ \mathrm{L}$ of wort.

\subsubsection{Fermentation accompaniment}

Five replicates of the experiment were carried out in $2 \mathrm{~L}$ flasks, containing a plastic tube adapted to the cover with its extremity immersed in distilled water. The working volume was $1 \mathrm{~L}$ and each experiment was carried out at room temperature until it was reached a constant alcoholic content. The mead obtained was then centrifuged (JANETZKI S 60) at 3,000 rpm for $20 \mathrm{~min}$, pasteurized $\left(65^{\circ} \mathrm{C} / 30 \mathrm{~min}\right)$ and kept frozen $\left(-18{ }^{\circ} \mathrm{C}\right)$ for further utilization in the acetic fermentation.

During the alcoholic fermentation, $20 \mathrm{~mL}$ samples were taken out every $12 \mathrm{~h}$. In these samples, the following components were determined: total sugars concentration, using the Clegg-Anthrone method (14) and ethanol, using the dichromate oxidation method (3).

\subsubsection{Yield and fermentation efficiency calculations}

During the alcoholic fermentation of sugars with the utilization of yeast, ethanol and carbon dioxide are the main products obtained in equimolar proportions. This mechanism was quantified for the first time by GayLussac, where $100 \mathrm{Kg}$ of glucose yields $51.1 \mathrm{Kg}$ of ethanol and $48.9 \mathrm{Kg}$ of carbon dioxide. The theoretical yield of $51.1 \%$ in weight is known as GayLussac coefficient, and is a basic data for efficiency conversion (12).

The ethanol concentration during the alcoholic fermentation was measured by volume. To calculate the yield, these values were converted to weight, using the ethanol's density value at $20^{\circ} \mathrm{C}$, that is 0.789 .

- Yield: produced alcohol (\% w/v) / consumed sugars (\% w/v) (2).

- Fermentation efficiency: [ (produced alcohol / theoretical alcohol from consumed sugars) $\times 100](9)$.

\subsection{ACETIC FERMENTATION}

Acetic fermentation was carried out in a vertical fermenter built in PVC with vegetable charcoal washed and sterilized as stuffing material. The fermenter's working volume was $15 \mathrm{~L}$. The fermentation was held at room temperature for the five replicates of the experiment. Vinegar containing acetic bacteria was inoculated to the fermenter. The vinegar circulated inside the fermenter until the microorganisms were activated. This was 
verified by the generator's internal temperature variation in comparison with room temperature. The alcoholic wort (mead) was then added with about $8 \%(\mathrm{v} / \mathrm{v})$ of alcohol content.

During the fermentation process, both the internal (generator) and the external (environment) temperature were monitored.

\subsubsection{Wort preparation and fermentation accompaniment}

The mead obtained at the alcoholic fermentation, with about $8 \%(\mathrm{v} / \mathrm{v})$ of alcohol content, was enriched with ammonium sulfate, $0.1 \mathrm{~g} / \mathrm{L}$; ammonium phosphate, $0.5 \mathrm{~g} / \mathrm{L}$; potassium citrate, $0.1 \mathrm{~g} / \mathrm{L}$ and magnesium sulfate, $0.1 \mathrm{~g} / \mathrm{L}$.

The addition of the alcoholic wort for vinegar production was conducted by taking out $4 \mathrm{~L}$ of vinegar with about $9 \%(\mathrm{w} / \mathrm{v})$ acidity and by adding the same quantity of alcoholic wort with $8 \%(\mathrm{v} / \mathrm{v})$ of alcohol content. Each alcoholic addition was considered as one repetition of the experiment. The mash circulation in the generator occurred at $7 \mathrm{~min}$ intervals. Aseptic techniques were not used during the wort preparation or during the acetic fermentation course.

During the acetification process, $50 \mathrm{~mL}$ samples were taken out from the mash, every $24 \mathrm{~h}$. The ethanol content and total acidity were determined in these samples, with three replicates (3).

The initial acidity and ethanol content determinations for each repetition were carried out one hour after the mixture had been circulating in the generator.

\subsubsection{Fermentation yield calculation}

The acetic fermentation efficiency was calculated and expressed in two ways: 1) acetic acid observed production compared with the theoretical yield - calculated from the ethanol consumption and from the stoichiometry of the conversion reaction of ethanol to acetic acid, where $1 \mathrm{~g}$ ethanol yields $1.304 \mathrm{~g}$ acetic acid (2); 2) total concentration or Gesammte Konzentration (GK), largely used in the vinegar industry, expressing fermentation efficiency as the sum of the ethanol (\% v/v) and acetic acid (\% $\mathrm{w} / \mathrm{v}$ ) concentrations at the beginning and at the end of the fermentation (11). This relation may be applied when calculating the conversion efficiency of ethanol to acetic acid: GK yield = (final GK / initial GK) $\times 100$. 


\subsection{SENSORIAL ANALYSIS}

Sensorial analysis of the honey vinegar was accomplished by a trained panel consisting of six judges who evaluated each sample five times. The arrangement of the samples at each session was according to a balanced block design for three samples. Each judge received three samples: alcohol vinegar (commercial trend), white wine vinegar (commercial trend) and honey vinegar, all of them with $4.2 \%$ acidity. Alcohol and white wine vinegar were chosen as standards for being widely consumed in Brazil.

To evaluate appearance, color and odour the samples were distributed in test tubes containing $10 \mathrm{~mL}$ each, while for flavor evaluation they were offered with lettuce leaves. The acceptability index was obtained from hedonic scale values considering $100 \%$ the highest value for the products in test received, and was considered accepted the sample which obtained a minimum index of $70 \%(13)$.

Analysis of variance was computed using the Statgraphics (8). When analysis of variance indicated a significant effect at $\mathrm{P}<0.05$ level, Tukey's test was used.

\section{RESULTS AND DISCUSSION}

\subsection{ALCOHOLIC FERMENTATION}

It was not necessary to make any $\mathrm{pH}$ correction of the wort, as it showed an initial $\mathrm{pH}$ of 4.5 , which is considered optimal for yeast activity. The fermentation was well managed at room temperature, which varied from $26{ }^{\circ} \mathrm{C}$ to $33^{\circ} \mathrm{C}$.

The wort had $17.11 \%(\mathrm{w} / \mathrm{v})$ total sugars concentration. The consumption determined at the end of the alcoholic fermentation was $15.22 \%(\mathrm{w} / \mathrm{v})$. This means that $88.95 \%$ of the total sugars present at the medium were utilized by the yeast.

The diluted honey alcoholic fermentation's yield (Table 1) was about $41 \mathrm{~g}$ ethanol/100 g fermentable sugar, representing an alcoholic fermentation efficiency of about $81 \%$. In practical experiments, even in optimal working conditions, the highest yield reached has not been above $48 \%$ and the yield has still been lower in industrial process (10).

Mead with alcohol content varying from $7.97 \%$ to $8.15 \%(\mathrm{v} / \mathrm{v})$ was obtained from the five replicates of the experiment. This data is comparable to the alcoholic content of $7.0-10.0 \%(\mathrm{v} / \mathrm{v})$ observed by VIDAL (16) when he produced mead using honey from sugar-cane. 


\section{TABLE 1 - TOTAL SUGAR CONSUMPTION, ETHANOL PRODUCTION, ALCOHOLIC FERMENTATION YIELD AND EFFICIENCY, IN FIVE REPLICATIONS OF THE EXPERIMENT}

\begin{tabular}{cccccc}
\hline Replicate & $\begin{array}{c}\text { Total sugars } \\
\text { consumption } \\
(\% \mathrm{w} / \mathrm{v})\end{array}$ & $\begin{array}{c}\text { Ethanol } \\
\text { production } \\
(\% \mathrm{w} / \mathrm{v})\end{array}$ & $\begin{array}{c}\text { Theoretical } \\
\text { ethanol } \\
(\% \mathrm{w} / \mathrm{v})\end{array}$ & $\begin{array}{c}\text { Yield } \\
(\%)\end{array}$ & $\begin{array}{c}\text { Efficiency } \\
(\%)\end{array}$ \\
\hline 1 & 15.13 & 6.304 & 7.731 & 41.67 & 81.54 \\
2 & 15.20 & 6.430 & 7.767 & 42.30 & 82.78 \\
3 & 15.24 & 6.304 & 7.787 & 41.36 & 80.95 \\
4 & 15.27 & 6.304 & 7.803 & 41.28 & 80.78 \\
5 & 15.26 & 6.288 & 7.798 & 41.21 & 80.63 \\
\hline$\overline{\mathrm{X}} \pm$ SD & $15.22 \pm 0.05$ & $6.326 \pm 0.058$ & $7.777 \pm$ & $41.56 \pm$ & $81.34 \pm 0.87$ \\
& & & 0.029 & 0.044 & \\
\hline
\end{tabular}

$\overline{\mathrm{X}}$ (mean); SD (standard deviation).

The sugar content was reduced from an initial value of $17.11 \%$ to less than $2 \%$ within $72 \mathrm{~h}$, in all replicates of the experiment, and the final alcohol concentration was about $8 \%(\mathrm{v} / \mathrm{v})$.

A typical alcoholic fermentation curve is showed at Figure 1. The highest rate of ethanol production occurred in the first $36 \mathrm{~h}$ of fermentation, when about $75 \%$ of the total ethanol had already been produced. BHATT et al. (4) obtained similar results observing higher alcohol production in a period of up to $35 \mathrm{~h}$ of fermentation, when they used a juice made of guava and damaged bananas to produce ethanol, with Saccharomyces cerevisiae as inoculum.

\subsection{ACETIC FERMENTATION}

The acetic fermentation occurred at room temperature, which varied from $20.4{ }^{\circ} \mathrm{C}$ to $27.9{ }^{\circ} \mathrm{C}$ during the five replicates. The internal generator's temperature varied from $21.2{ }^{\circ} \mathrm{C}$ to $30{ }^{\circ} \mathrm{C}$. The highest temperature increase observed in the generator regarding the external temperature was $3{ }^{\circ} \mathrm{C}$. However, this increase was not enough to cause loss and reduce the fermentation yield. The acetic fermentation is not affected if there is a temperature variation from $26{ }^{\circ} \mathrm{C}$ to $32{ }^{\circ} \mathrm{C}$ at each two-hour interval (6).

Figure 2 shows the average of ethanol consumption and the average of acetic acid production regarding fermentation time (h) in the five replications. It is possible to notice that vinegar with up to $9 \%$ acidity was produced in $72 \mathrm{~h}$ with a residual alcohol content of about $1 \%$. 
FIGURE 1 - TOTAL SUGARS CONSUMPTION MEAN \% W/V (O) AND ETHANOL PRODUCED MEAN \% V/V (-) IN 84 HOURS OF ALCOHOLIC FERMENTATION

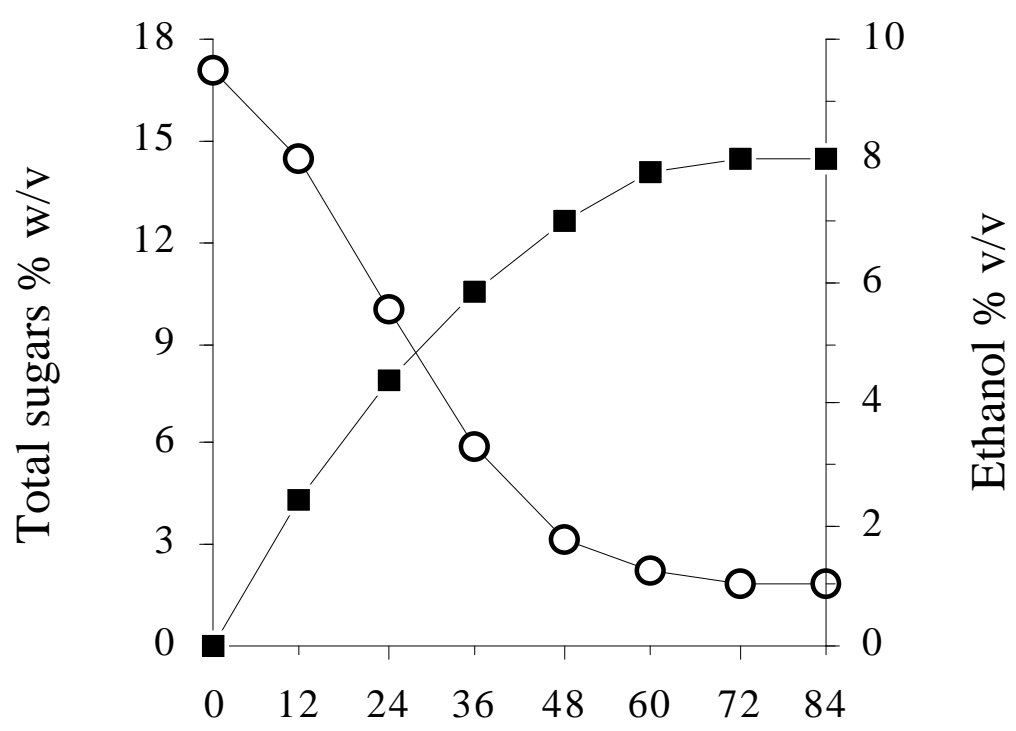

Time (h)

FIGURE 2 - ETHANOL CONSUMPTION MEAN \% V/V (0) AND ACETIC ACID PRODUCED MEAN \% W/V (-) IN 72 HOURS OF ACETIC FERMENTATION

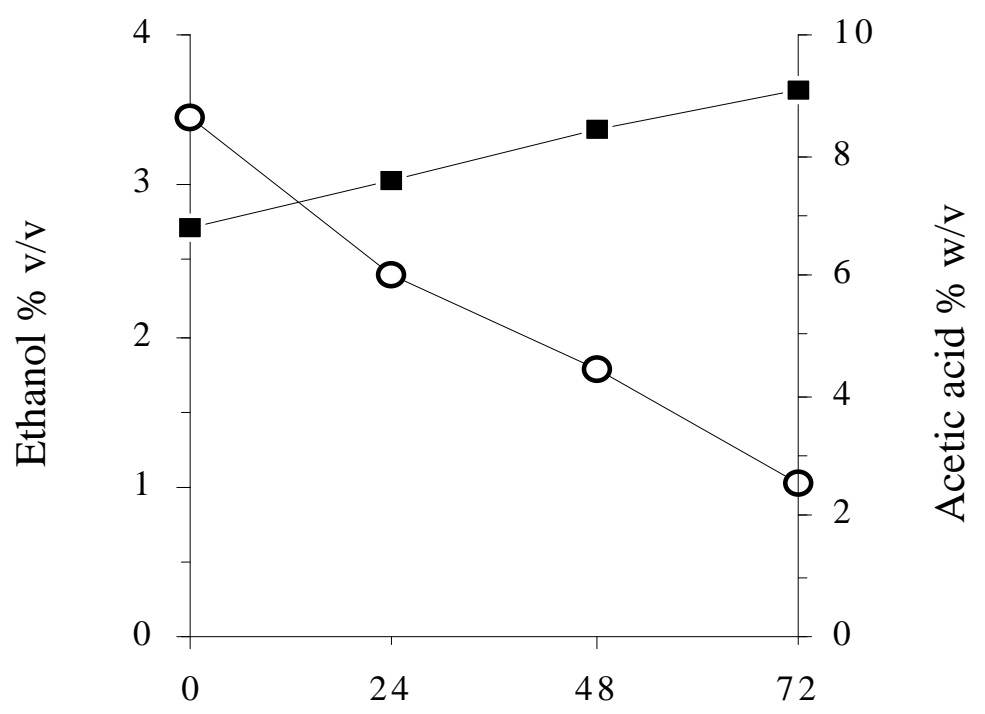

Time (h) 
The residual alcohol is partially transformed into vinegar and partially converted into esters during storage, giving the vinegar the characteristic flavor of the raw material utilized in the acetification process (2).

According to the stoichiometryc reaction of ethanol transformation into acetic acid, $1 \mathrm{~g}$ ethanol may produce $1.304 \mathrm{~g}$ acetic acid, and the conversion of $1 \mathrm{~g}$ of ethanol into $1 \mathrm{~g}$ of acetic acid $(76.7 \%$ yield) is considered economic for industrial purposes (2).

Table 2 shows the acetic fermentation yield of the five replicates of the experiment. In all replicates the yield was higher than $90 \%$, reaching a $97.21 \%$ yield, which means that the process was economic.

The results showed on Table 2 and the curves of Figure 2 show that it is possible to obtain economic yields in $72 \mathrm{~h}$ if the initial acidity and ethanol content are suitable.

\section{TABLE 2 - ETHANOL CONSUMPTION, ACETIC ACID PRODUCTION AND ACETIC FERMENTATION YIELD OF THE FIVE REPLICATES OF THE EXPERIMENT}

\begin{tabular}{ccccc}
\hline Replicate & $\begin{array}{c}\text { Ethanol } \\
\text { consumption } \\
(\% \mathrm{w} / \mathrm{v})\end{array}$ & $\begin{array}{c}\text { Acetic acid } \\
\text { production } \\
(\% \mathrm{w} / \mathrm{v})\end{array}$ & $\begin{array}{c}\text { Theoretical acetic } \\
\text { acid }(\% \mathrm{w} / \mathrm{v})\end{array}$ & $\begin{array}{c}\text { Yield } \\
(\%)\end{array}$ \\
\hline 1 & 1.847 & 2.210 & 2.409 & 91.73 \\
2 & 1.673 & 1.990 & 2.181 & 91.24 \\
3 & 1.989 & 2.430 & 2.594 & 93.67 \\
4 & 2.036 & 2.580 & 2.654 & 97.21 \\
5 & 1.989 & 2.400 & 2.594 & 92.52 \\
\hline$\overline{\mathrm{X}} \pm \mathrm{SD}$ & $1.907 \pm 0.148$ & $2.322 \pm 0.227$ & $2.486 \pm 0.193$ & $93.27 \pm 2.384$ \\
\hline
\end{tabular}

$\overline{\mathrm{X}}$ (mean); SD (standard deviation).

Some authors $(1,11)$ used the GK or total concentration to calculate the fermentation yield. In an efficient acetification process, $1 \mathrm{~mL}$ ethanol yields $1.036 \mathrm{~g}$ of acetic acid. Without losses resulting from evaporation or superoxidation, the total concentration or GK (ethanol content $\mathrm{v} / \mathrm{v}+$ acetic acid concentration $\mathrm{w} / \mathrm{v}$ ) remains constant during the acetification period (11). 
The relation observed by HROMATKA \& EBNER (1959) may be applied when calculating the efficiency of ethanol conversion to acetic acid: GK yield $=($ final GK/initial GK) $\times 100$. Nevertheless, this yield GK (Table 3$)$ is always higher than that calculated by the ratio acetic acid produced/theoretical acetic acid.

\section{TABLE 3 - ACETIC ACID PRODUCTION AND YIELD GK OF THE FIVE REPLICATES OF THE EXPERIMENT}

\begin{tabular}{cccccc}
\hline Replicate & $\begin{array}{c}\text { Acetification } \\
\text { period } \\
(\mathrm{h})\end{array}$ & $\begin{array}{c}\text { Ethanol } \\
(\% \mathrm{v} / \mathrm{v})\end{array}$ & $\begin{array}{c}\text { Acetic acid } \\
(\% \mathrm{w} / \mathrm{v})\end{array}$ & GK & Yield GK (\%) \\
\hline \multirow{2}{*}{1} & 0 & 3.38 & 7.15 & 10.53 & \\
& 72 & 1.04 & 9.36 & 10.40 & 98.76 \\
2 & 0 & 3.41 & 6.90 & 10.31 & \\
& 72 & 1.29 & 8.89 & 10.18 & 98.73 \\
3 & 0 & 3.70 & 6.30 & 10.00 & \\
& 72 & 1.18 & 8.73 & 9.91 & 99.10 \\
4 & 0 & 3.23 & 6.64 & 9.87 & \\
& 72 & 0.65 & 9.22 & 9.87 & 100.00 \\
& 0 & 3.51 & 6.91 & 10.42 & \\
\hline
\end{tabular}

$\mathrm{GK}=$ Gesammte Konzentration .

Vinegar removal and reposition of the same volume with alcoholic wort whenever the alcoholic concentration reached levels of about $1 \%$ and the acetic acid concentration reached $9 \%$, allowed the GK to remain constant, indicating that there were no losses resulting from evaporation or overoxidation during the acetification process. Approximately $5 \mathrm{~L}$ of honey vinegar with $9 \%$ acetic acid $(\mathrm{w} / \mathrm{v})$ were obtained from $1 \mathrm{Kg}$ of bee honey.

\subsection{SENSORIAL ANALYSIS}

Analysis of variance of the scale results showed no significant differences $(P>0.05)$ for appearance or flavor among honey vinegar and the standard vinegars (alcohol and white wine).

Significant differences $(\mathrm{P}<0.05)$ were found for color and odour. Tukey's test showed that for color, honey vinegar (8.533) differed statistically from white wine (7.933) and alcohol (7.533) vinegars and had superiors scores. 
For odour, Tukey's test showed that honey vinegar (7.116) and white wine vinegar were statistically similar and both differed from alcohol vinegar (6.100).

All attributes of honey vinegar showed acceptability index over $70 \%$ : $95.37 \%$ for appearance, $94.81 \%$ for color, $79.07 \%$ for odour and $75.56 \%$ for flavor, indicating that the vinegar produced would show good consumer acceptability.

\section{CONCLUSION}

It was possible to produce mead with ideal alcoholic content for utilization in the production of honey vinegar by utilizing commercial yeast (Saccharomyces cerevisiae) as inoculum without the need of sophisticated equipment.

The acetic fermentation of mead using quick process showed yields which can be considered of economical feasibility. Sensorial analysis through the acceptability index indicated that honey vinegar may be accepted by consumers.

\section{Abstract}

It was utilized bee honey (Apis mellifera) for vinegar obtention, with the perspective of honey derived products diversification. The wort was prepared by diluting honey in distilled water to $21 \%$ total solids and by adding ammonium sulfate and ammonium phosphate. Saccharomyces cerevisiae was inoculated to the wort $(4 \mathrm{~g} / \mathrm{L})$. Alcoholic fermentation was carried out at room temperature during 24 hours. In this study, $1 \mathrm{Kg}$ of honey yielded about $5 \mathrm{~L}$ of wine, containing about $8 \%$ alcohol $(\mathrm{v} / \mathrm{v})$, from a wort with $17.11 \%$ total sugars $(\mathrm{w} / \mathrm{v})$. The efficiency of the alcoholic fermentation was $81.34 \%$. The acetic fermentation was performed by quick process in a $15 \mathrm{~L}$ vertical fermenter. This resulted in a vinegar containing up to $9 \%$ of acetic acid $(\mathrm{w} / \mathrm{v})$ and about $1 \%$ of alcohol $(\mathrm{v} / \mathrm{v})$. The acetic fermentation yielded between 91.24 and $97.21 \%$. Approximately $5 \mathrm{~L}$ of honey vinegar with $9 \%$ acetic acid (w/v) were obtained from $1 \mathrm{Kg}$ of bee honey. All attributes of honey vinegar showed acceptability index over $70 \%: 95.37 \%$ for appearence, $94.81 \%$ for colour, $79.07 \%$ for odour and $75.56 \%$ for flavour, indicating it would show good consumer acceptability.

\section{BIBLIOGRAPHIC REFERENCES}

1 ADAMS, M. R., TWIDDY, D. R. Performance parameters in the quick vinegar process. Enzyme Microbiology and Technology, v. 9, p. 369-373, June, 1987. 
AQUARONE, E., ZACANARO JÚNIOR, O. Vinagres. In: AQUARONE, E., LIMA, U. A., BORZANI, W. (Coords.).

Alimentos e bebidas produzidos por fermentação. São Paulo : E. Blücher, 1983. p. 104-122. (Biotecnologia, v. 5). methods of analysis. 14.ed. Arlington, 1984. $1141 \mathrm{p}$.

4 BHATT, S., RANA, R. S., NAIN, L. R. Ethanol production from mixed fruit juice of damage guava and banana. Journal of Food Science and Technology, v. 24, p. 192-193, July/Aug., 1987.

5 BOLUN, S., YIPU, Z. Exploitation and utilization of low quality honey resources and study on buckwheat honey beer. In: INTERNATIONAL CONGRESS OF APICULTURE, 32., 1989, Rio de Janeiro. Anais... Bucharest : Apimondia, 1989. p. 34-35.

6 EBNER, H. Vinegar. In: REED, G. (ed.). Industrial microbiology. Westport : AVI, 1982. p. 802-834.

7 FAO. Tropical and sub-tropical apiculture. Roma, 1986. p. 156252. (FAO Agricultural Services Bulletin, 68).

8 GRAPHIC SOFTWARE SYSTEMS, Inc. STATGRAPHICS: statistical graphics system, version 7.0. USA, 1985-93.

9 HANG, Y. D., LEE, C. Y., WOODAMS, E. E. et alii. Production of alcohol from apple pomace. Applied and Environmental Microbiology, v. 42, n. 6, p. 1128-1129, Dec., 1981.

10 HASHIZUME, T. Fundamentos de tecnologia do vinho. In: AQUARONE, E., LIMA, U. A., BORZANI, W. (Coords.).

Alimentos e bebidas produzidos por fermentação. São Paulo : E. Blücher, 1983. p. 14-19 (Biotecnologia, v. 5).

11 HROMATKA, O., EBNER, $\mathrm{H}$. Vinegar by submerged oxidative fermentation. Industrial and Engineering Chemistry, v. 51, n. 10, p. 1279-1280, Oct., 1959.

12 JACKMAN, E. A. Alcohol industrial. In: BU'LOCK, J., KRISTIANSEN, B. Biotecnología básica. Zaragoza : Acríbia, 1991. p. 320-321.

13 MONTEIRO, C. L. B. Técnicas de avaliação sensorial. 2. ed. Curitiba : CEPPA, 1984. $101 \mathrm{p}$.

14 NOVOA, M. A. O., PALACIOS, C. A. M., LEÓN, E. R. M. Manual de técnicas para laboratório de nutrición de peces y crustaceos. México : ONU, 1993. p. 33-35. (Doc. de Campo, 7). 
15 SANTA CATARINA. Síntese anual da agricultura de Santa

Catarina. Florianópolis : Instituto CEPA, 1995. v. 1, p.150-152.

16 VIDAL, R. Comportamento de coleta do "mel de cana" por abelhas do gênero Apis e estudo do aproveitamento desse alimento. São Paulo, 1983. 98 p. Dissertação (Mestrado), em Ciências Biológicas) - Instituto de Biociências, Universidade Estadual Paulista "Júlio de Mesquita". 